\title{
Research on Aesthetic Image of Miyanishi's "You are Umasou" Picture Book Adaptation Film
}

\author{
Nan Gao \\ Dalian Neusoft Institute of Information \\ Dalian, China 116033
}

\author{
Liya Fu \\ Dalian Neusoft Institute of Information \\ Dalian, China 116033
}

\begin{abstract}
In the contemporary society of cultural innovation, with the gradual enrichment of materials, people's demands for spiritual pursuits are getting higher and higher. The forms, contents, narratives and styles of picture-making art have become the research hotspots. In the process of developing cultural industry, the culture of fans is prevalent. The excellent picture books have become potential IP resource. Also, they are the resources of animation derivative products and film and television adaptations. The adaptation of Miyanishi's picture book "You are Umasou" is worthy of careful study by the domestic cultural industry and the animation professional teaching unit. The theoretical research results of this paper are expected to contribute theoretical power to the creation of Chinese picture books and animation and film works.
\end{abstract}

Keywords-picture book adaptation; Miyanishi; You are Umasou

\section{INTRODUCTION}

It is "picture book" in English. In Japanese, people would use "绘本" to express this meaning [1]. Picture book is a form of literary and artistic works which is mainly based on pictures and written narrative. Some of these works also have no words, all of which are narrated through images, such as "Grey Lady \& Strwbry Snat". Some works are described in a few words, such as "999 tadpoles" of Kangcheng Murakami's works, leaving large imaginative space to the readers. The variety and style of picture books are the inevitable result of the diversification of culture.

In the current context of cultural innovation and crossover cooperation, the picture book works would realize the dynamic display of static content combining with the development of science and technology, such as enhanced reality technology, digital technology, network technology, computer graphics technology, and the diversified crossborder development of tablet personal computer platforms such as APPs applications, etc. This has opened up the development space of the picture book. However, it is subject to media, technology and communication methods, and needs to be constantly improved. The other form is the film adaptation of the picture book. It is in line with the aesthetic needs of the contemporary audience. For example, the famous American comic book adaptation "Spider-Man" has achieved the success of the box office of the movie, and its image resources have been continuously developed and utilized. The derived series of movies, toys, costumes and props have become successful cases of culture and business. The picture book "My Neighbor Totoro" by Japanese anime master Miyazaki Hayao was published by Japan Dessori Bookstore [2]. This picture book was created by Master Miyazaki Hayao in 1986. It was adapted into an animated film and familiarized with more audiences. The simplicity of his country life and the innocent emotions of children are vividly displayed through dynamic images. The harmonious coexistence between man and nature, man and animal, man and living creature, and the green humanistic feelings constitute an important aesthetic acceptance experience through the picture, which has affected the audience and readers for several generations. In 2016, the phenomenal movie "Monkey King: Hero is Back", which was adapted from Wu Chengen's "Journey to the West", started a beautiful combination of boxing in domestic anime movies. The values and feelings from the publicity and distribution to the film are accurately conveyed. It has injected spiritual impetus to domestic fans, fans of watching movies and disseminators of Chinese culture.

\section{THE WRITING STYLE OF MIYANISHI}

"You are Umasou" is the masterpiece of the famous Japanese picture book writer Miyanishi. The picture painter was born in Shizuoka Prefecture of Japan in 1956 and graduated from the Fine Arts Department of the Faculty of Arts of the Japanese University [3]. This witty and peaceful master of picture books was engaged in graphic design work in the early days, and then gradually turned to the creation of picture books. He gained creative inspiration from his childhood experiences, social history, parenting experience and life perceptions. With simple abstract images and animal characters, he would make the metaphor of the characters in the society. At the same time, he would integrate the warm story. The stupid wild wolf Ulu in the story, the slender and resourceful pink pigs, the fierce carnivorous tyrannosaurus or weak frogs have together built a series of stories, which are full of warmth. Miyanishi creates the protagonist with simple lines and expresses values with stories of affection, love and friendship. These animal characters carry meaningful social metaphors, telling people that no matter what their appearances are, they have kindness, hope and dreams in the heart. This kind of values has universal value and is suitable for reading from children to adults. As Miyanishi said in an interview, "My picture books are created with themes. I want 
to use my picture book story to "infect" love and kindness to countless children." [4]

\section{THE AESTHETIC EXPERIENCE OF PICTURE BOOK "YOU ARE UMASOU"}

Miyanishi's picture book "You are Umasou" is one of the seven works. According to the stories in the series of picture books, the relationship between father and son is the happiest; there is no difference among kind people; the most beautiful friendship; the mother-child relationship across the race; and the kindness is the most beautiful virtues; meeting a bosom friend is happiness; brotherhood and parent-child love. This series of picture books use the dinosaur image to metaphorize the relationship among modern society, family, friends, and enemies. However, no matter how the appearance and wealth is, people would have beauty and goodness, hope and ideal in the heart. This is the author's beautiful vision expressed in the series of works. It also hopes that young readers will construct the spirit and values when they are not in contact with the real society. In the image design, the author uses rough lines. The cover uses the characters with a genuine format design. Also, it is the embodiment of the author's aesthetic design style and design strategy. In many picture books, it is prominent and attracts the attention.

\section{THE AESTHETIC ACCEPTANCE OF ADAPTED FILM "YOU ARE UMASOU"}

"The picture book is like a static movie, using picture narrative. Regardless of the medium, the picture book has the narrative gene of film history." The film adaptation of "You are Umasou" picture book is undoubtedly successful. This film produced by Miyanishi, also directed by Masaya Fujimori, was released in Japan in June 2010. Chinese douban movies scored more than 8.5 points. It has collected fresh picture style, stupid character design, good and beautiful values, aesthetic function with healing mind, realworld identity and many other aesthetic elements, which have together constructed successful adaptation of the picture book. At the same time, the adaptation of this picture book has achieved the successful setting of the aging movie. This is what we have been exploring in the development of Chinese animation film. Low-aged children can see family and friendship from the movie. Adults can find their own position in the social role in the movie. At the same time, it can evoke the memories of childhood.

\section{A. Character Modelling, and Scene Design Style}

The main character of the movie version, Tyrannosaurus Hart, is the Japanese pronunciation of the English word "heart". It represents double meanings of mind and sincerity. There is no big difference in the proportion of the overall shape from the original picture book. However, in the design line, the strokes in the film version are more delicate. At the same time, in order to meet the requirements of cinema screening, the brightness of the overall picture is bright and vivid. The colors of the original picture book are mostly drawn in solid colors suitable for children to read and recognize. In the movie version, it follows the rules of color usage techniques of Japanese anime movies.

The scene design of the film is beautiful. The scene design of the natural landscape carries the green naturalistic feelings of Miyazaki Hayao. At the same time, it has the romantic imagination of the plants during the Jurassic period. At the end of the film, it depicts the fall of the volcanic ash. The world has been faint pink. The volcanic ash, which symbolizes death, is decorated like cherry blossom petal, and the earth is decorated in pink, which is consistent with the Japanese sorrowful plot. The style of this film scene is characterized by obvious Japanese animation movies.

\section{B. The Narrative Style and Structure of Drama}

The video art of film version of "You are Umasou" is very commercial in the narrative style of the drama. It is produced in the format of strict Japanese anime film industry, introducing the first drama conflict in the opening. That is, the mother of the herbivorous dragon faces the problem of leaving or staying of the cub of tyrannosaurus, which may be a natural enemy. This kind of problem is a problem for the biological class, especially for the human being. In the first ten minutes of the whole film, the audience's emotions will be effectively mobilized. And then, with the growth of Hart, it begins the second conflict of drama. He finds that he is different from his brother, especially in the preferences of food. He intentionally restrains himself. In the end, when a malicious companion points out his type, he has to endure a strong inner struggle. It once again puts the audience's emotions at a high point. The dramatic characters in Western literary generally choose to leave home. This is the best choice for them. For example, Hamlet in Shakespeare's works, and Oedipus in the Greek mythology chose to run away from home at this point. This plot may be the best choice for the herbivorous mother.

After the Anime film "Snow White" produced by Disney in the United States, the addition of music elements in anime movies has become customary link. In the bright, powerful and relaxed music background, the model of Tyrannosaurus Hart is same as other heroic types of film works. And a road of self-redemption was carried out. In the process, there were failures, successes, laughter and tears. At the same time, it perfectly combines with the rhythm of background music.

The third emotional conflict was when Hart met the small Ankylosaurus "うまそう (Umasou)", which was originally a small Ankylosaurus egg that Hart wanted to eat. The relationship, love and kindness between the pseudo father and the son were slowly carried out. On the surface, Hart was disgusted with "うまそう (Umasou)". It was actually very concerned and worried. The small Ankylosaurus unconditionally trust, follow-up and understanding Hart, which conveyed the finest and warmth of the world's best parent-child relationship. Hart faced the choice of whether to separate from the small Ankylosaurus. It was the third drama conflict in the film to. The small Ankylosaurus expressed that he wouldn't separate from the father of Tyrannosaurus. Tyrannosaurus deceived him if he could reach the top of the mountain in the opposite direction, he would never leave 
small Ankylosaurus. The small Ankylosaurus desperately ran to the top of the mountain to accomplish the goal beyond his current ability, exhausting the strength. In this scene, the conflicts between family and son, the conflicts of spirit, and other conflicts made the film more cruel and warm. This is also commonly used conflict expression technique in Japanese anime films. When the characters have reached their limits, it is the most exciting and lively moment in the drama.

The fourth emotional conflict was to face the volcanic eruption. Hart looked for a herbivorous dragon, and the mother and son reunited. The mother said, "Why did you run away without saying a word, do you know how worried your mother was at that time?" Hart said to his adoptive mother, "Mom, it is the best that you are safe and sound." "Sorry, I grew up like this." "It doesn't matter; I can see it at a glance. You are the best-behaved Hart in my mind." The most simple and warm dialogue between mother and son after the departure is full of humanity. The emotions in this film once again punctuated.

The final climax is the confrontation between Tyrannosaurus Hart and his biological father, and the separation between the mother and the child. In the dialogue between the mother Herbivorous dragon and the Tyrannosaurus Hart, "Umasou", the herbivorous dragon and Brother Wright merged into four points, getting smaller and smaller. And the greatest feeling between heaven and earth-love, was released at this time.

Although this film combines the contents of the picture book in the process of adaptation, it is completed according to the production mode of Japanese anime commercial film. The setting of the drama conflict, the dialogue design of the character can fully reflect the personality of the character. It obtained the audience's recognition in the process of filming. A good aesthetic experience is achieved.

\section{Values and Emotional Communication}

The value of this film is highly consistent with the author's own picture book. Although it is a story about the dinosaur world, every character can find a counterpoint in modern society. Tyrannosaurus may be the strongest in physical strength or wealth in the real society. The herbivorous dragons may be the ordinary people in the real society. Ankylosaurus represents idealized personality that is kind and pure. No matter what kind of role or what kind of appearance, there is goodness in the depths of the heart. At the same time, there are many plots that the weak beat the strong in the film. In the real society, people may be temporarily weak or inferior, as long as you have dreams and hopes, persist in hard work and inspire the spirit, you may win and be strong. The transmission of such values has profound meaning in any context.

\section{CONCLUSION}

Excellent picture books are important media in early childhood education. And their social and historical values become more and more prominent. Excellent picture books can stimulate children's imagination and creativity, language description ability. The children can feel the author's feelings and values, as well as the reality and ugliness, kindness and beauty in social life. It reveals how to cope with and solve difficulties in the future in social life and communication. The expansion of the "ageing" of the audience of animation works to the "entire aging" has played a positive role in the construction of the world outlook, outlook on life and values of children and adults.

\section{REFERENCES}

[1] Dong Lili. "Study of the Characteristics of Miyanishi's Dinosaur's Warm Story Picture Book" [M], Modern Communication. September 2016, P112 董丽丽. 《宫西达也<恐龙的温馨故事绘本>的特点研 究》, [M]现代交际.2016 年 9 月, P112

[2] Lu Xuefei. "Characteristics of the Adaptation Film of Children's Picture Book" [M], Chinese Literature Review. December 2017, P54 卢雪菲. 《儿童绘本改编影片的造型特点》[M]中国文艺评论.2017 年 12 月, P54

[3] Zou Chenghui. "Significance of Reading Miyanishi's Dinosaur Picture Book" [M], Yue Haifeng. April 2015, P98 邹承辉.《宫西达 也恐龙绘本的阅读意义》[M]粤海风.2015 年 4 月, P98

[4] Liu Yang. "Miyanishi: "Infecting the Inner Love and Kindness to the Children" [J] December 5, 2014, 010th edition 柳漾. 《宫西达也: 将内心的爱和善良“传染”给孩子》[J]2014 年 12 月 5 日第 010 版

[5] Fang Rui, Kong Xiaoyan. "The Strategy and Practice of Narrative Performance of Electronic Children's Picture Book Based on Movie Language" [M] Science and Technology and Publishing. January 2017, P69 方睿.孔晓燕. 《基于电影语言的电子儿童绘本叙事表 现策略与实践》 $[\mathrm{M}]$ 科技与出版.2017 年 1 月刊，P69 